\title{
PENGARUH KEJELASAN SASARAN ANGGARAN DAN PARTISIPASI ANGGARAN TERHADAP KINERJA APARAT PEMERINTAH DAERAH KOTA MANADO
}

\author{
Nikita Angelita Maria Nangoy \\ Jullie J. Sondakh \\ Harijanto Sabijono
}

\author{
Fakultas Ekonomi Dan Bisnis, Jurusan Akuntansi \\ Universitas Sam Ratulangi Manado. \\ Email : nikitanangoy@yahoo.com \\ julliesondakh@yahoo.com \\ h_sabijono@yahoo.com
}

\begin{abstract}
Indonesian Law Number 46 of 2011 on Civil Servant Performance Appraisal will help develop effectivity and efficiency of employee performances to reach the objection and vision and mission of a regional administration.The purpose of this study was to determine whether the clarity of budge targeting and budget participation has effect by partial and by simultaneous on the performance of the government officials. The hypothesis was tested using $t$ test and then $f$ test. The population number in this study is 441 people. And, the samples were 30 people of lower managers and staffs in financial and reporting department. The research method used questionnaire with Likert scale measurement. The analytical method used in this research was multiple regression analysis in which the process of data analysis was performed with the aid of computer technology SPSS version 22. The results of the analysis by the t test states that the clarity of budget targeting variables $X 1=i s$ $0.317>0.005$, it means that $H_{0}$ is accepted and $H_{a}$ rejected, which in other words the clarity of budget targeting does not affect the performance of government officials. Participation budget $X 2=i$ is $0.001<0.005$, this means that $H_{a}$ is accepted and $H_{0}$ is rejected, which in other words budget participation does affect the performance of government officials. The results of the analysis through $F$ test shows that the level of significance of the variables $X 1$ and $X 2$ is $0.002<0.005$, this means that $H_{0}$ is rejected and $H_{a}$ accepted; in other words, X1 and X2 simultaneously have a significant effect on the performance of government officials $(Y)$.
\end{abstract}

Keywords: clarity of budget targeting, budget participation, performance of local government officials

\section{Latar Belakang}

\section{PENDAHULUAN}

Reformasi tahun 1998 telah membuka wacana perubahan manajemen keuangan pemerintah. Terkait pelaksanaan otonomi daerah, pemerintah mengeluarkan Undang-Undang Nomor 32 Tahun 2004 yang telah diamandemenkan dengan Undang-Undang Nomor 23 Tahun 2014 tentang Pemerintahan Daerah mengenai penyelenggaraan pemerintahan daerah diarahkan untuk mempercepat terwujudnya kesejahteraan masyarakat melalui peningkatan pelayanan, pemberdayaan dan peran serta masyarakat dengan memperhatikan prinsip demokrasi, pemerataan, keadilan dan kekhasan suatu daerah. Ini pun melahirkan paradigma dalam pelaksanaan otonomi daerah yang meletakan otonomi penuh, luas, dan bertanggung jawab pada daerah.

Perubahan reformasi yang paling dominan adalah pada aspek pemerintahan. Sebagai organisasi sektor publik, pemerintah daerah dituntut agar memiliki kinerja yang berorientasi pada kepentingan masyarakat dan mendorong pemerintah agar senantiasa tanggap akan tuntutan lingkungannya, dengan berupaya memberikan pelayanan terbaik secara transparan dan berkualitas serta adanya pembagian tugas yang baik pada pemerintahan tersebut. Tuntutan yang semakin tinggi diajukan terhadap pertanggungjawaban yang diberikan oleh penyelenggara negara atas kepercayaan yang diamanatkan kepada mereka. Dengan kata lain, kinerja instansi pemerintah kini lebih banyak mendapat sorotan karena masyarakat sering memonitor setiap perencanaan pemerintah dalam satu periode. Selain itu, tuntutan atas perubahan organisasi publik baik secara individu ataupun anggota kelompok sangat diharapkan 
perubahan ini sering ditujukan kepada aparatur pemerintah menyangkut prestasi kerja yang diberikan kepada organisasi. Menurut Kuntomoro (2005 : 103, dalam Rafika 2010) kinerja organisasi publik adalah hasil akhir (output) organisasi yang sesuai dengan tujuan organisasi, transparan dalam pertanggungjawaban, efisien, sesuai dengan kehendak pengguna jasa informasi, visi dan misi organisasi, berkualitas, adil, serta dilaksanakan dengan sarana dan prasarana yang memadai.

Menurut UU No. 23 Tahun 2014, daerah otonom meliputi daerah propinsi, daerah kabupaten, dan daerah kota. Di dalam daerah otonom terdapat satuan kerja perangkat daerah (SKPD) yang merupakan unit pemerintahan di lingkungan pemda selaku pengguna anggaran, yang dapat berbentuk dinas, badan dan kantor ataupun satuan. Sebagai pengguna anggaran, SKPD harus menyelenggarakan sistem akuntansi guna menghasilkan laporan keuangan sebagai bentuk pertanggungjawaban penggunaan anggaran yang dikelolanya.

Dalam rangka meningkatkan keinformatifan laporan keuangan pemerintah, dan untuk menghasilkan pengukuran kinerja yang lebih baik, serta memfasilitasi manajemen keuangan/asset yang lebih transparan dan akuntabel, maka perlu diterapkan kejelasan sasaran anggaran dan partisipasi anggaran.

Undang-undang No 33 Tahun 2004 tentang perimbangan keuangan antara pusat dan daerah, membawa fundamental dalam hubungan tata pemerintah dan hubungan keuangan, sekaligus membawa perubahan penting dalam pengelolaan anggaran daerah. Anggaran sebagai suatu rencana kegiatan dalam suatu periode yang direpresentasikan dalam bentuk rencana pendapatan dan belanja dalam satuan moneter yang berbentuk suatu dokumen yang menggambarkan kondisi keuangan dari pemerintahan yang meliputi pendapatan, belanja dan aktivitas (Sujarweni, 2015 : 28). Anggaran dapat dijadikan sebagai manifestasi dari rencana yang akan dicapai dimasa yang akan datang dan pada masa yang sama budget dapat menjadi alat kontrol.

Kejelasan sasaran anggaran akan membantu aparat untuk mencapai kinerja yang diharapkan, dimana dengan mengetahui sasaran anggaran maka tingkat kinerja dapat tercapai. Adanya sasaran anggaran yang jelas, maka akan mempermudah untuk mempertanggungjawabkan keberhasilan atau kegagalan pelaksanaan tugas organisasi dalam rangka untuk mencapai tujuan-tujuan dan sasaran-sasaran yang telah ditetapkan sebelumnya. Ketidakjelasan sasaran anggaran akan menyebabkan pelaksana anggaran menjadi bingung, tidak tenang dan menyebabkan pelaksana anggaran tidak termotivasi untuk mencapai kinerja yang diharapkan (Kenis, 1979 dalam Syafrial, 2009). Agar anggaran tepat sasaran dan sesuai tujuan maka diperlukan kerja sama yang baik antara bawahan dan atasan dalam penyusunan anggaran yang dinamakan dengan partisipasi anggaran.

Partisipasi dalam penyusunan anggaran pemerintah adalah salah satu cara untuk menciptakan sistem pengendalian manajemen yang baik sehingga diharapkan dapat mencapai sasaran kinerja. Adanya partisipasi anggaran dengan melibatkan satuan kerja perangkat daerah (SKPD) dalam penyusunan anggaran (APBD) daerah akan meningkatkan tanggung jawab serta kinerja aparatur. Keikutsertaan para tingkat manager level menengah dan bawah dalam penentuan anggaran akan mendapatkan keputusan yang lebih realistis sehingga tercipta gambaran sasaran visi dan misi suatu daerah.

\section{Rumusan Masalah} sebagai berikut :

Berdasarkan latar belakang permasalahan yang ada, adapun rumusan masalah dalam penelitian

1. Apakah kejelasan sasaran anggaran memiliki pengaruh terhadap kinerja aparat pemerintah daerah?

2. Apakah partisipasi anggaran memiliki pengaruh terhadap kinerja aparat pemerintah daerah?

3. Apakah kejelasan sasaran anggaran dan partisipasi anggaran memiliki pengaruh terhadap kinerja aparat pemerintah daerah?

\section{Tujuan Penelitian}

Berdasarkan dari uraian yang dikemukakan pada latar belakang penelitian, maka tujuan dari penelitian ini adalah : 
1. Untuk mengetahui pengaruh kejelasan sasaran anggaran terhadap kinerja aparat pemerintah daerah.

2. Untuk mengetahui pengaruh partisipasi anggaran terhadap kinerja aparat pemerintah daerah.

3. Untuk mengetahui pengaruh kejelasan sasaran anggaran dan partisipasi anggaran terhadap kinerja aparat pemerintah daerah.

\section{Manfaat Penelitian}

Manfaat yang diharapkan dari penelitian ini adalah :

1. Penelitian ini diharapkan mampu memberikan tambahan informasi maupun bahan masukan, sebagai bahan pertimbangan dan sumbangan pemikiran didalam pengambilan keputusan serta mewujudkan program kerja dan merencanakan perbaikan pada kegiatan di periode berikutnya serta meningkatkan kinerja aparat pemerintah untuk membentuk lembaga pemerintahan yang lebih baik.

2. Penelitian ini kiranya dapat memberikan informasi mengenai pengaruh kejelasan sasaran anggaran dan partisipasi anggaran terhadap kinerja aparat pemerintah daerah Kota Manado.

\section{Kejelasan Sasaran Anggaran}

\section{TINJAUAN PUSTAKA}

Deddi Noerdiawan (2010 : 20) menyatakan bahwa penetapan tujuan spesifik akan lebih produktif daripada tidak menetapkan tujuan spesifik yang akan mendorong pegawai untuk melakukan yang terbaik bagi pencapaian tujuan yang dikehendaki. Adanya sasaran anggaran yang jelas, maka akan mempermudah untuk mempertanggungjawabkan keberhasilan atau kegagalan pelaksanaan tugas organisasi dalam rangka untuk mencapai tujuan-tujuan dan sasaran-sasaran yang telah ditetapkan sebelumnya. Sasaran yang tidak jelas dapat menyebabkan kebingungan, tekanan dan ketidakpuasan dari pegawai. Pimpinan organisasi dapat meningkatkan kepuasan kerja, menurunkan ketegangan kerja, dan memperbaiki anggaran yang dihubungkan dengan sikap, kinerja anggaran, dan efisiensi biaya. Oleh sebab itu, kejelasan sasaran anggaran daerah harus dinyatakan secara jelas, spesifik dan dapat dimengerti oleh mereka yang bertanggung-jawab untuk menyusun dan melaksanakannya.

\section{Partisipasi Anggaran}

Partisipasi anggaran menurut Kennis (1979, dalam Kewo C.K 2014) dapat didefinisikan sebagai berikut : Participation in budgeting as how much as how much further a manager involved in the budget preparation and the influence of managers on budget goals organizational unit which becomes their responsibility.

Maksudnya adalah partisipasi anggaran sebagai tingkat keikutsertaan manajer dalam menyusun anggaran dan pengaruh anggaran tersebut terhadap pusat pertanggungjawaban manajer yang bersangkutan.

\section{Kinerja Aparat Pemerintah Daerah}

Menurut Mangkunegara (2007 : 67, dalam Mila Suhardini 2014) kinerja berasal dari kata job performance atau actual performance (prestasi kerja atau prestasi sesungguhnya yang dicapai oleh seseorang). Menurut Kamus Besar Bahasa Indonesia aparat pemerintah daerah adalah pegawai negeri yang berada di luar politik, bertugas melaksanakan administrasi pemerintahan dalam suatu daerah berdasarkan perundang-undangan yang telah ditetapkan. Maka kinerja aparat pemerintah daerah adalah prestasi seseorang atau seorang aparatur dalam melaksanakan administrasi pemerintahan sesuai peraturan perundang-undangan yang telah ditetapkan.

\section{Penelitian Terdahulu}

Penelititan pertama yaitu Manus (2009) dengan judul Pengaruh Kejelasan Sasaran Anggaran Terhadap Kinerja Aparat Pemerintah Pada Dinas Pendapatan Daerah dan Bagian Keuangan Kota 
Manado. Dalam penelitiannya peneliti menggunakan metode kuantitaf dengan pengukuran skala likert. Teknik pengumpulan data dengan menggunakan kuesioner. Metode ini berisi daftar pertanyaan yang mencerminkan kondisi pegawai atau staf dalam suatu satuan kerja perangkat daerah, yaitu kejelasan sasaran anggaran berpengaruh positif dalam kinerja aparat pemerintah Kota Manado.

Terdapat kesamaan yang terdapat dalam penelitian Manus (2009) dengan penelitian yang akan dilakukan yakni pada variabel sasaran anggaran sebagai variabel independen dan variabel kinerja aparat pemerintah sebagai variabel dependen. Namun penulis mengembangkan penelitian ini dengan menambah satu variabel partisipasi anggaran sebagai variabel independen.

Penelitian lainnya yaitu dari Shelly Jelita Akhmad, Emrinaldi Nur DP, dan Julita (2014) dengan judul Pengaruh Pertisipasi Anggaran, Kejelasan Tujuan Anggaran Terhadap Kinerja Aparat Pemerintah Daerah : Komitmen organisasi, Budaya Organisasi dan Locus of Control sebagai Variabel Moderating. Metode yang dipakai peneliti adalah analisis regresi linear berganda. Jenis penelitian yang dipakai merupakan jenis eksplanatif dan teknik penelitian yang dilakukan adalah teknik kuesioner.

Persamaannya terletak pada metode yang dipakai dalam penelitian ini menggunakan penelitian analisis regresi linear berganda. Perbedaannya terletak pada variabel moderating yang tidak dipakai oleh penulis.

\section{Kerangka Pemikiran Teoritis}

Hubungan Kejelasan Sasaran Anggaran Dengan Kinerja Aparat Pemerintah Daerah

Penemuan empiris yang berkaitan dengan kejelasan sasaran anggaran dengan kinerja aparat pemerintah daerah memberikan hasil yang beragam. Peneliti menduga bahwa kejelasan sasaran anggaran dapat menghasilkan ketidakkonsisten akan kinerja dari aparat pemerintah. Ini dapat disebabkan adanya ketidakjelasan sasaran anggaran yang mengakibatkan pelaksanaan menjadi bingung serta tidak puas dalam bekerja. Maka dengan adanya sasaran anggaran yang jelas maka akan memudahkan individu menyusun target-target anggaran. Selanjutnya, target-target anggaran yang disusun akan sesuai dengan sasaran yang ingin dicapai organisasi, sehingga semakin tinggi tingkat kejelasan sasaran anggaran akan berpengaruh terhadap meningkatnya kinerja pemerintahan daerah. Dugaan ini akan diuji dalam hipotesis sebagai berikut :

$\mathrm{H}_{01}$ : Kejelasan sasaran anggaran tidak berpengaruh signifikan terhadap kinerja aparat pemerintah daerah. $\mathrm{H}_{\mathrm{a} 1}$ : Kejelasan sasaran anggaran berpengaruh signifikan terhadap kinerja aparat pemerintah daerah.

\section{Hubungan Partisipasi Anggaran Dengan Kinerja Aparat Pemerintah Daerah}

Adanya partisipasi anggaran oleh aparat pemerintah daerah maka aparat tersebut berusaha untuk bertanggung jawab terhadap tugas yang diembannya. Dengan adanya tanggung jawab ini maka akan menjadikan kinerja yang baik bagi organisasi pemerintah, sehingga semakin tingginya partisipasi aparat pemerintah daerah akan meningkatkan kinerja di satuan pemerintah daerah. Dugaan ini akan diuji dalam hipotesis sebagai berikut :

$\mathrm{H}_{02}$ : Partisipasi anggaran tidak berpengaruh signifikan terhadap kinerja aparat pemeritah daerah.

$\mathrm{H}_{\mathrm{a} 2}$ : Partisipasi anggaran berpengaruh signifikan terhadap kinerja aparat pemeritah daerah.

\section{Hubungan Kejelasan Sasaran Anggaran dan Partisipasi Anggaran Dengan Kinerja Aparat Pemerintah Daerah}

Hubungan dari kejelasan sasaran anggaran dan partisipasi anggaran merupakan perwujudan dari karakteristik dalam penganggaran. Ini bisa dibuktikan dalam proses penyusunan anggaran dimana rencana program atau kegiatan yang disusun oleh suatu SKPD dibahas dalam suatu rapat kerja penyusunan anggaran dimana baik kepala SKPD, kepala bidang, kepala sub bidang, kepala bagian, kepala sub bagian sampai dengan staf yang merupakan utusan dalam mengikuti rapat penyusunan anggaran.

Dugaan ini akan diuji dalam hipotesis sebagai berikut :

$\mathrm{H}_{03}$ : Partisipasi anggaran tidak berpengaruh signifikan terhadap kinerja aparat pemeritah daerah.

$\mathrm{H}_{\mathrm{a} 3}$ : Partisipasi anggaran berpengaruh signifikan terhadap kinerja aparat pemeritah daerah. 


\section{Hipotesis Penelitian}

Hipotesis merupakan proposisi yang akan diuji keberlakuannya, atau merupakan suatu jawaban sementara atas pertanyaan penelitian (Prasetyo\&Jannah,2010 : 76). Hipotesis yang diajukan dalam penelitian ini dengan mengacu pada latar belakang penelitian, rumusan masalah, tujuan dan manfaat penelitian serta tinjauan pustaka, adalah :

$\mathrm{H}_{01}$ : Kejelasan sasaran anggaran tidak berpengaruh secara signifikan terhadap kinerja aparat pemerintah daerah.

$\mathrm{H}_{\mathrm{a} 1}$ : Kejelasan sasaran anggaran berpengaruh secara signifikan terhadap kinerja aparat pemerintah daerah.

$\mathrm{H}_{02}$ : Partisipasi anggaran tidak berpengaruh secara signifikan terhadap kinerja aparat pemerintah daerah.

$\mathrm{H}_{\mathrm{a} 2}$ : Partisipasi anggaran berpengaruh secara signifikan terhadap kinerja aparat pemerintah daerah.

$\mathrm{H}_{03}$ : Kejelasan sasaran anggaran dan partisipasi anggaran tidak berpengaruh terhadap kinerja aparat pemerintah daerah.

$\mathrm{H}_{\mathrm{a} 3}$ : Kejelasan sasaran anggaran dan partisipasi anggaran berpengaruh terhadap kinerja aparat pemerintah daerah.

\section{Jenis Penelitian}

\section{METODE PENELITIAN}

Jenis data yang digunakan dalam penelitian ini adalah data kuantitatif atau data yang dapat diolah dan dianalisis dengan teknik perhitungan matematika atau statistika, dengan menggunakan skala likert.

\section{Tempat dan Waktu Penelitian}

Penelitian ini dilaksanakan di 3 SKPD, yaitu Badan Perencanaan Pembangunan Daerah, Badan Pengelola Keuangan dan Aset Daerah dan Badan Kepegawaian dan Diklat Daerah. Beralamat di Jalan Balai Kota, Tikala Ares. Penelitian mulai dilaksanakan pada bulan April tahun 2016.

\section{Populasi dan Sampel Populasi}

Populasi merupakan kelompok elemen yang lengkap, yang biasanya berupa orang, objek, transaksi atau kejadian dimana kita tertarik untuk mempelajarinya atau menjadi objek penelitian (Kuncoro, 2009:103). Populasi dalam penelitian ini adalah aparat pemerintah yang ada di SKPD yang berupa badan di Kota Manado dengan jumlah 441 orang.

\section{Sampel}

Menurut Gay dan Diehl (1996, dalam Kuncoro 2009b : 111), secara umum jumlah sampel untuk studi korelasional, dibutuhkan minimal 30 sampel untuk menguji ada tidaknya hubungan. Teknik penarikan sampel dalam penelitian ini menggunakan purposive sampling yaitu metode sampling yang dilakukan dalam mengambil orang-orang yang terpilih menurut ciri-ciri khusus yang dimiliki oleh sampel.

Kriteria-kriteria yang diambil untuk dijadikan sampel antara lain :

1. Satuan Kerja Perangkat Daerah (SKPD) berupa badan kota Manado.

2. Responden merupakan lower manajer dan staf dari SKPD kota Manado.

Berdasarkan kriteria-kriteria diatas maka dipilih 30 sampel sebagai responden.

\section{Metode Pengumpulan Data}

1. Metode Pengumpulan Kepustakaan (library Research)

Pengumpulan data ini dilakukan untuk memperoleh data sekunder yang digunakan sebagai landasan teori yang berkaitan dengan masalah yang diteliti.

2. Penelitian lapangan (Field Research) 
Yaitu penelitian data secara langsung dengan mengadakan penelitian terhadap objek yang diteliti untuk memperoleh data primer, dengan melakukan :

a. Wawancara, yaitu metode penelitian yang dilakukan dengan cara komunikasi langsung dengan pihak-pihak yang berhubungan objek penelitian dengan mengajukan pertanyaan-pertanyaan yang telah disiapkan terlebih dahulu mengenai masalah-masalah yang akan diteliti.

b. Kuesioner, yaitu alat bantu bagi penulis dalam melakukan penelitian. Metode ini dilakukan dengan cara mengajukan pertanyaan tertutup, yaitu bentuk pertanyaan yang dilengkapi atau disertai dengan jumlah alternative atau kategori jawaban, sehingga responden tinggal memilih salah satu alternative kategori pilihan jawaban tersebut sesuai dengan pilihannya.

\section{Metode Analisis \\ Uji Validitas dan Reliabilitas}

Sugiyono (2010b : 172), ketentuan validitas instrument sahih apabila $r$ hitung lebih besar dari $r$ kritis $(0,30)$. Sujianto (2009: 97), item pernyataan atau pertanyaan dinyatakan valid jika mempunyai nilai $r$ hitung yang lebih besar dari $r$ standar yaitu 0,3. Sugiyono (2010c : 173), bila korelasi tiap faktor positif dan besarnya 0,3 ke atas maka faktor tersebut merupakan construct yang kuat. Jadi, validitas menunjukan seberapa cermat suatu alat tes melakukan fungsi ukurnya atau suatu alat ukur yang dapat mengukur apa yang ingin diukur.

Anwar (2011 : 139) mengatakan reliabilitas merupakan penerjemahan dari kata reliability yang artinya keterpercayaan, keterandalan, konsistensi, dan sebagainya. Hasil pengukuran dapat dipercaya bila dalam beberapa kali pelaksanaan pengukuran terhadap kelompok subjek yang sama diperoleh hasil yang relatif sama, selama aspek yang diukur tidak berubah. Sugiyono (2011 : 42), jika skala itu dikelompokan kedalam lima kelas denegan range yang sama, maka ukuran kemantapan alpha dapat diinterpretasikan sebagai berikut :

1. Nilai Alpha Cronbach's 0,00 sampai dengan 0,20, berarti kurang reliabel.

2. Nilai Alpha Cronbach's 0,21 sampai dengan 0,40, berarti agak reliabel.

3. Nilai Alpha Cronbach's 0,41 sampai dengan 0,60, berarti cukup reliabel.

4. Nilai Alpha Cronbach's 0,61 sampai dengan 0,80 berarti reliabel.

5. Nilai Alpha Cronbach's 0,81 sampai dengan 1,00 berarti sangat reliabel.

Riduwan (2012:7), reliabilitas suatu konstruk variabel dikatakan baik jika memiliki nilai Alpha Cronbach's >0,60.

\section{Statistik Deskriptif dan Statistik Induktif}

Menurut Wirawan (2009 : 70), "statistik deskriptif adalah statistik dimana tingkat pengerjaannya mencakup cara-cara pengumpulan, menyusun atau mengatur, mengolah, menyajikan dan menganalisis data angka agar dapat memberikan gambaran yang teratur, ringkas dan jelas mengenai keadaan, peristiwa, atau gejala tertentu sehingga dapat ditarik pengetian atau makna tertentu." Menurut Usman \& R.P.S. Akbar (2008 : 69) menyatakan bahwa "statistik induktif merupakan suatu alat untuk mengumpulkan data, mengolah data, menarik kesimpulan dan membuat keputusan berdasarkan analisis data yang dikumpulkan." Adapun secara keseluruhan analisis data ini menggunakan bantuan komputer dengan Software program SPSS version 22.0 For Windows.

\section{Uji Asumsi Klasik}

Untuk memperoleh hasil regresi yang baik dan linier serta tidak bias digunakan uji asumsi klasik, yaitu :

$\begin{array}{ll}\text { a. } & \text { Asumsi Klasik Heteroskedastisitas } \\ \text { b. } & \text { Asumsi Klasik Autokorelasi } \\ \text { c. } & \text { Multikolinearitas } \\ \text { d. } & \text { Normalitas }\end{array}$




\section{Analisis Regresi Berganda}

Untuk menghitung besarnya pengaruh variabel bebas (X) terhadap variabel tak bebas (Y), maka dilakukan perhitungan dengan menggunakan metode analisis regresi linear berganda. Dalam penelitian ini, metode tersebut digunakan untuk mengetahui seberapa besar pengaruh Kejelasan Sasaran Anggaran $\left(\mathrm{X}_{1}\right)$ dan Partisipasi Anggaran $\left(\mathrm{X}_{2}\right)$ terhadap Kinerja Aparat Pemerintah Daerah (Y). Untuk menyelesaikan analisis data ini secara keseluruhan digunakan Software program SPSS version 22.0 For Windows, dan semua hasil output data yang dihasilkan kemudian diinterpretasikan satu per satu termasuk didalamnya menentukan koefisien korelasi ( $\mathrm{R}$ ) dan koefisien determinasi $\left(\mathrm{R}^{2}\right)$.

Metode ini merupakan regresi yang berbentuk linear dimana bentuk ini secara teoritis variabel tidak bebas yang akan diteliti merupakan kecenderungan hubungan yang linear terhadap masing-masing variabel bebasnya (Sumarsono, 2009b : 82).

Untuk menguji hipotesis yang diajukan, maka digunakan statistik uji t dan uji F. Pengujian hipotesis dengan uji $t$ untuk koefisien regresi parsial sebagai berikut $: \mathrm{H}_{01}$ artinya kejelasan sasaran anggaran tidak berpengaruh secara signifikan terhadap kinerja aparat pemerintah daerah. $\mathrm{H}_{\mathrm{a} 1}$ artinya kejelasan sasaran anggaran berpengaruh secara signifikan terhadap kinerja aparat pemerintah daerah. $\mathrm{H}_{02}$ artinya partisipasi anggaran tidak berpengaruh secara signifikan terhadap kinerja aparat pemerintah daerah. $\mathrm{H}_{\mathrm{a} 2}$ artinya partisipasi anggaran berpengaruh secara signifikan terhadap kinerja aparat pemerintah daerah. Uji $\mathrm{F}$ adalah untuk menguji pengaruh variabel bebas secara bersama-sama. Pengujian hipotesis dengan uji $\mathrm{F}$ sebagai berikut : $\mathrm{H}_{03}$ artinya variabel kejelasan sasaran anggaran dan partisipasi anggaran tidak berpengaruh secara signifikan terhadap kinerja aparat pemeritah daerah. $\mathrm{H}_{\mathrm{a} 3}$ artinya variabel kejelasan sasaran anggaran dan partisipasi anggaran berpengaruh secara signifikan terhadap kinerja aparat pemerintah daerah.

\section{Definisi dan Pengukuran Variabel}

Variabel adalah sesuatu yang dapat membedakan atau mengubah nilai (Kuncoro, 2009d : 41). Dalam penelitian ini digunakan dua macam variabel yaitu variabel terikat atau variabel dependen (Y) dan variabel bebas atau variabel independen $(\mathrm{X})$.

Dalam menganalisis data, penulis menggunakan dua variabel bebas dan satu variabel terikat dalam penelitian, yaitu :

1. Variabel kejelasan sasaran anggaran $\left(\mathrm{X}_{1}\right)$

Kejelasan sasaran anggaran merupakan tujuan anggaran yang ditetapkan secara jelas dan spesifik agar dapat dimengerti oleh orang-orang yang bertanggungjawab atas pencapaian sasaran anggaran tersebut. Variabel ini menggunakan kuesioner sebanyak 5 pertanyaan dan diukur dengan menggunakan satuan skor.

2. Variabel partisipasi anggaran $\left(\mathrm{X}_{2}\right)$

Partisipasi anggaran diyakini dapat mampu membangun suatu interaksi yang lebih baik antara pemimpin dan bawahan sehingga tercipta komitmen yang kuat dalam merealisasi target anggaran kearah lebih baik. Variabel ini menggunakan kuesioner sebanyak 6 pertanyaan dan diukur dengan menggunakan satuan skor.

3. Kinerja aparat pemerintah (Y)

Pengukuran kinerja pemerintah daerah diarahkan pada masing-masing satuan kerja telah diberi wewenang mengelola sumber daya sebagaimana bidangnya. Variabel ini menggunakan kuesioner sebanyak 9 pertanyaan dan diukur menggunakan skor.

\section{Hasil Penelitian}

\section{HASIL PENELITIAN DAN PEMBAHASAN}

Hasil uji heteroskedastisitas, grafik scatterplot (tabel 1) Kejelasan Sasaran Anggaran (X1), Partisipasi Anggaran (X2) dan Kinerja Aparat Pemerintah Daerah (Y) menunjukan penyebaran titik-titik data tidak berpola, titik-titik data menyebar diatas dan dibawah atau disekitar angka 0 , dan titik-titik data tidak mengumpul hanya diatas dan dibawah atau disekitar angka 0 , dan titik-titik data tidak mengumpul 
hanya diatas atau dibawah saja dengan tingkat signifikansi berada diatas 0,05 pada tabel Coefficients, yang artinya penelitian ini tidak mengalami gejala heteroskedastisitas. Hasil uji autokorelasi (tabel 2) menunjukan angka Durbin Watson sebesar 1,999. Jadi, karena 1,65 < 1,999 <2,35, maka penelitian ini tidak ada autokorelasi. Hasil uji multikolinearitas (tabel 3) menunjukan nilai VIF < 10 dan tolerance > 0,1. Maka disimpulkan kejelasan sasaran anggaran, partisipasi anggaran dan kinerja aparat pemerintah tidak mengalami multikolinearitas. Hasil uji normalitas (tabel 4), grafik Normal Q-Q Plot Of Regresion Unstandardized Residual (tabel 5) pada variabel Kejelasan Sasaran Anggaran (X1), Partisipasi Anggaran (X2) dan Kinerja Aparat Pemerintah Daerah (Y) dinyatakan terdistribusi normal karena gambar distribusi dengan titik-titik data yang menyebar disekitar garis diagonal dan penyebaran titik-titik data searah mengukuti garis diagonal.

Koefisien Korelasi (R) (tabel 6) yang dihasilkan antara variabel Kejelasan Sasaran Anggaran (X1), Partisipasi Anggaran (X2) dan Kinerja Aparat Pemerintah Daerah (Y) adalah 0,599. 0,599 menunjukan nilai antara 0 sampai +1 , artinya antara variabel X1, variabel X2, dan Variabel Y mempunyai hubungan yang cukup kuat. Hal ini berarti dengan Kejelasan Sasaran Anggaran dan Partisipasi Anggaran mempunyai hubungan yang cukup kuat yang mana dapat mempengaruhi kualitas dari kinerja aparat yang akan dihasilkan.

$R$ Square atau koefisien determinasi adalah 0,359 artinya 35,9\% dari variasi Kinerja Aparat Pemerintah Daerah dapat dijelaskan melalui variabel Kejelasan Sasaran Anggaran dan Partisipasi Anggaran. Sedangkan sisanya yaitu sebesar 0,641 atau 64,1\% dipengaruhi oleh faktor-faktor lain yang tidak diteliti dalam penelitian ini.

Hasil dari uji t model persamaan regresi menunjukan :

Konstanta $\alpha$ sebesar 5,368 memberikan pengertian bahwa variabel Kejelasan Sasaran Anggaran (X1) dan Partisipasi Anggaran (X2) sama dengan nol (0), maka variabel Kinerja Aparat Pemerintah Daerah (Y) sebesar 5,368 satuan skor.

Nilai b1 yang merupakan koefisien regresi dari variabel Kejelasan Sasaran Anggaran (X1) sebesar 0,509 ini mempunyai arti bahwa jika Kejelasan Sasaran Anggaran meningkat sebesar 1 satuan skor, maka akan mengalami peningkatan nilai Kinerja Aparat Pemerintah Daerah sebesar 0,509 satuan skor dari kondisi sebelumnya, dengan asumsi variabel lainnya tetap. Ini berarti jika Kejelasan Sasaran Anggaran di tetapkan dengan matang maka akan berpengaruh positif terhadap tercapainya sasaran visi dan misi suatu daerah.

Nilai b2 yang merupakan koefisien regresi dari variabel Partisipasi anggaran (X2) sebesar 0,647 ini mempunyai arti bahwa jika Partisipasi Anggaran meningkat sebesar 1 satuan skor, maka akan mengalami peningkatan nilai Kinerja Aparat Pemerintah Daerah sebesar 0,647 satuan skor dari kondisi sebelumnya, dengan asumsi variabel lainnya tetap. Ini berarti jika Partisipasi Anggaran sangat mempengaruhi kualitas dari penyusunan anggaran, apabila Partisipasi Anggaran dilakukan secara merata dan saling melibatkan atasan dan bawahan maka hasil penyusunan anggaran akan semakin baik.

Pengujian hipotesis pada uji t (tabel 7) untuk mengetahui pengaruh setiap variabel dependen terhadap variabel independen secara parsial dengan menggunakan kriteria yaitu apabila signifikan $<0,05$ maka $\mathrm{H}_{0}$ ditolak, $\mathrm{H}_{\mathrm{a}}$ diterima dan apabila signifikan > 0,05 maka $\mathrm{H}_{0}$ diterima, $\mathrm{H}_{\mathrm{a}}$ ditolak.

Dari tabel 7 (lampiran) diketahui bahwa tingkat signifikansi dari variabel Kejelasan Sasaran Anggaran (X1) adalah 0,317 > 0,05 hal ini berarti $\mathrm{H}_{0}$ diterima dan $\mathrm{H}_{\mathrm{a}}$ ditolak, dengan kata lain Kejelasan Sasaran Anggaran tidak berpengaruh secara signifikan terhadap variabel Kinerja Aparat Pemerintah Daerah (Y). Dengan demikian hipotesis yang mengatakan Kejelasan Sasaran Anggaran (X1) tidak berpengaruh secara signifikan terhadap Kinerja Aparat Pemerintah Daerah (Y) diterima dan hipotesis yang mengatakan bahwa Kejelasan Sasaran Anggaran (X1) berpengaruh secara signifikan terhadap Kinerja Aparat Pemerintah Daerah (Y) ditolak. Dan variabel Partisipasi Anggaran (X2) diketahui tingkat signifikansinya adalah $0,001<0,05$ hal ini berarti bahwa $\mathrm{H}_{0}$ ditolak dan $\mathrm{H}_{\mathrm{a}}$ diterima dengan kata lain Partisipasi Anggaran berpengaruh secara signifikan terhadap variabel Kinerja Aparat Pemerintah Daerah (Y). Dengan demikian hipotesis yang mengatakan Partisipasi Anggaran (X2) berpengaruh secara signifikan terhadap variabel Kinerja Aparat Pemerintah Daerah (Y) diterima dan menolak hipotesis yang 
mengatakan Partisipasi Anggaran (X2) tidak berpengaruh secara signifikan terhadap Kinerja Aparat Pemerintah Daerah (Y).

Pengujian hipotesis pada uji $\mathrm{F}$ untuk mengetahui pengaruh seluruh variabel dependen terhadap variabel independen secara simultan dengan menggunakan kriteria, yaitu apabila signifikan $<0,05$ maka $\mathrm{H}_{0}$ ditolak dan $\mathrm{H}_{\mathrm{a}}$ diterima dan apabila signifikan >0,05 maka $\mathrm{H}_{0}$ diterima $\mathrm{H}_{\mathrm{a}}$ ditolak. Dari tabel 8 (lampiran) diketahui bahwa tingkat signifikansi dari variabel Kejelasan Sasaran Anggaran (X1) dan Partisipasi Anggaran (X2) adalah 0,002 < 0,05 hal ini berarti bahwa $\mathrm{H}_{0}$ ditolak dan $\mathrm{H}_{\mathrm{a}}$ diterima, dengan kata lain secara simultan Kejelasan Sasaran Anggaran (X1) dan Partisipasi Anggaran (X2) berpengaruh secara signifikan terhadap Kinerja Aparat Pemerintah Daerah (Y).

\section{Kesimpulan}

\section{PENUTUP}

Dari uraian yang telah penulis kemukakan, maka dapat ditarik kesimpulan sebagai berikut :

1. Hasil penelitian menggambarkan bahwa Kejelasan Sasaran Anggaran (X1) tidak berpengaruh secara signifikan terhadap variabel Kinerja Aparat Pemerintah Daerah (Y).

2. Hasil penelitian menggambarkan bahwa Partisipasi Anggaran (X2) berpengaruh secara signifikan terhadap variabel Kinerja Aparat Pemerintah Daerah (Y).

3. Hasil penelitian menggambarkan bahwa Kejelasan Sasaran Anggaran (X1) dan Partisipasi Anggaran (X2) berpengaruh secara signifikan terhadap Kinerja Aparat Pemerintah Daerah (Y).

\section{Saran}

Hasil penelitian ini sekiranya dapat memotivasi penelitian yang akan datang, untuk melakukan penelitian lebih lanjut yang berkaitan dengan kinerja aparat pemerintah daerah. Saran yang dapat diberikan berdasarkan hasil penelitian adalah :

1. Dengan adanya pengaruh Kejelasan Sasaran Anggaran dan Partisipasi Anggaran terhadap Kinerja Aparat Pemerintah Kota Manado maka disarankan kepada pihak pemerintah kota agar dalam penyusunan sasaran dan penetapan anggaran dapat dilaksanakan dengan sebaik-baiknya sehingga dapat dimengerti oleh orang yang bertanggung jawab untuk menyusun serta melaksanakannya. Selain itu perlu dilaksanakannya penyempurnaan serta kejelasan dalam sasaran anggaran sehingga dapat mengevaluasi kinerja aparat pemerintah demi tercapainya visi, misi dan tujuan suatu daerah.

2. Penelitian selanjutnya hendaknya mempertimbangkan variabel bebas lain yang dapat memperkuat kinerja aparat pemerintah daerah Kota Manado. Sesuai dengan penelitian sebelumnya, penulis menyarakan variabel bebas seperti, akuntabilitas publik, komitmen organisasi, budaya organisasi, locus of control, dan desentralisasi atau menjadikan variabel tersebut sebagai variabel pemoderasi maupun variabel intervening dalam penelitian yang akan dilakukan. Hasil penelitian ini dapat digunakan sebagai acuan untuk melakukan penelitian lainnya yang berhubungan dengan variabel atau objek penelitian ini, serta diharapkan penelitian ini dapat dipakai untuk pengembangan ilmu pengetahuan dibidang akuntansi sektor publik.

\section{DAFTAR PUSTAKA}

Kewo C.K.,2014. The Effect Of Participative Budgeting, Budget Goal Clarity And Internal Control Implementation On Managerial Performance. Thesis. Padjadjaran University Indonesia. Vol.5. No.12.

Kuncoro, Mudrajat. 2009. Metode Riset Untuk Bisnis dan Ekonomi. Jakarta: Erlangga.

Manus L.P.J, 2009. Pengaruh Kejelasan Sasaran Anggaran Terhadap Kinerja Aparat Pemerintah Pada Instansi Pemerintah Kota Manado. Skripsi. Universitas Sam Ratulangi Manado. 
Mila Suhardini, Kamaliah, M.Rasuli, 2014. Pengaruh Partisipasi Dalam Penyusunan Anggaran, Kejelasan Sasaran Anggaran, Struktur Desentralisasi, Dan Sistem Teknologi Informasi Terhadap Kinerja Manajerial Pemerintah Daerah. Tesis. Universitas Riau Pekanbaru.

Prasetyo, Bambang, dan Lina Miftahul Jannah, 2010. Metode Penelitian Kuantitatif Teori dan Aplikasi. Jakarta: Raja Grafindo Persada.

Rafika, 2010. Pengaruh Partisipasi Anggaran Dan Komitmen Organisasi Terhadap Kinerja SKPD Pemerintahan Kabupaten Labuhan Batu. Skripsi. Universitas Sumatera Utara.

Republik Indonesia, 2004. Undang-Undang Nomor 1 Tentang Perbendaharaan Negara. Jakarta: Sekretariat Negara.

Republik Indonesia, 2014. Undang-Undang Nomor 23 Tentang Pemerintahan Daerah. Jakarta: Sekretariat Negara.

Shelly, Akhmad dan Julita. 2014.Pengaruh Partisipasi Anggaran Dan Komitmen Organisasi Terhadap Kinerja SKPD Pemerintahan.

Sugiyono, 2010. Metode Penelititan Bisnis. Bandung: Alfabeta.

Sugiyono, 2011. Metode Penelitian Kuantitatif Kualitatif dan R\&D. Bandung: Alfabeta.

Sujarweni Wiratna V, 2015. Akuntansi Sektor Publik, Penerbit : Pustaka Baru Press.

Sumarsono, Sonny. 2009. Ekonomi Sumber Daya Manusia dan Ketenagakerjaan. Yogyakarta: Graha Ilmu.

Syafrial. 2009. Pengaruh Ketepatan Skedul Penyusunan Anggaran, Kejelasan Sasaran Anggaran, dan Partisipasi Penyusunan Anggaran terhadap Kinerja Manajerial SKPD pada Pemerintah Kabupaten Sarolangun. Tesis. Sekolah Pascasarjana Universitas Sumatera Utara.

Usman, Husaini \& Purnomo Setiady Akbar, 2008, Metodologi Penelitian Sosial, Jakarta: PT. Bumi Aksara

Wirawan, 2009. Evaluasi Kinerja Sumber Daya Manusia: Teori, Aplikasi dan Penelitian. Jakarta:

Salemba Empat.

\section{LAMPIRAN}

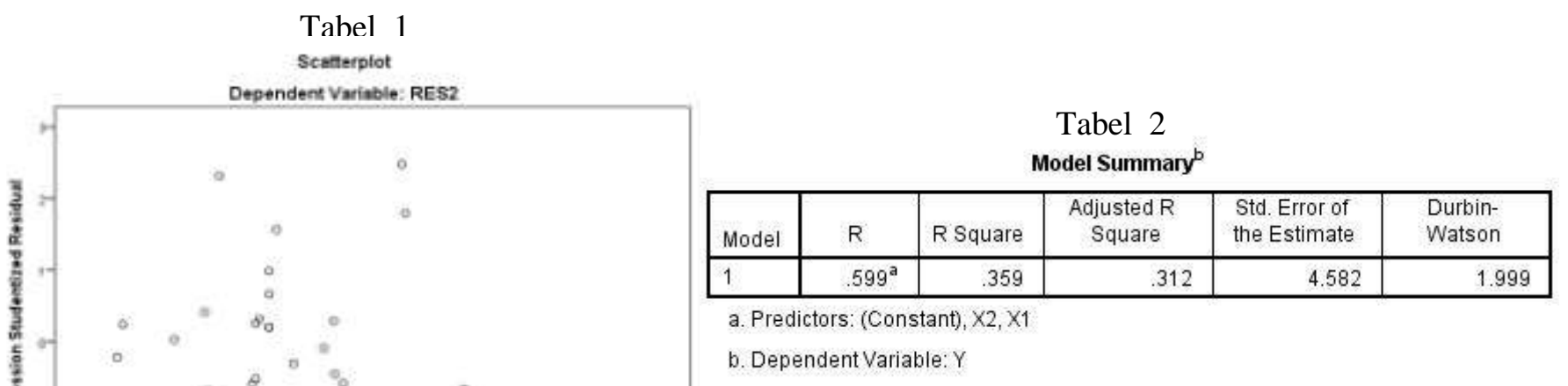

Tahel 3

Coefficients $^{\mathrm{a}}$

\begin{tabular}{|c|c|c|c|c|c|c|c|c|}
\hline \multirow[b]{2}{*}{ Mod } & & \multicolumn{2}{|c|}{ Unstandarcized Coeffcients } & \multirow{2}{*}{$\begin{array}{c}\begin{array}{c}\text { Standardioed } \\
\text { Coeficients }\end{array} \\
\text { Beta }\end{array}$} & \multirow[b]{2}{*}{ t } & \multirow[b]{2}{*}{ Sig. } & \multicolumn{2}{|c|}{ Colinearity Statistics } \\
\hline & & B & Std. Emor & & & & Telerance & VF \\
\hline \multirow[t]{3}{*}{1} & (Constant) & 5.368 & 10.858 & & .494 & 625 & & \\
\hline & $\mathrm{x} 1$ & 509 & .498 & .157 & 1.020 & 317 & 997 & 1.003 \\
\hline & $x$ & 647 & 175 & 570 & 3.683 & 001 & 997 & 1.003 \\
\hline
\end{tabular}

a. Dependent Variable: $Y$

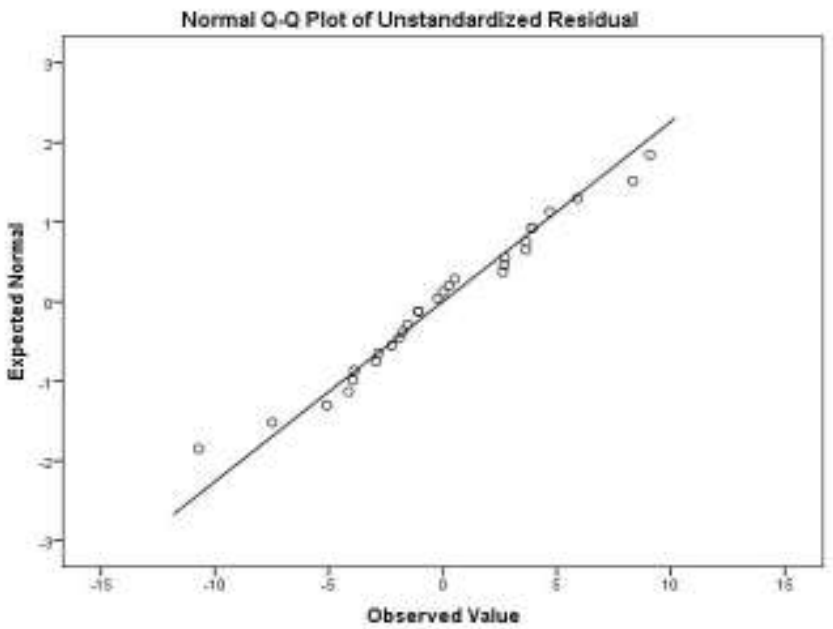


Tabel 4

Tests of Normality

\begin{tabular}{|l|r|r|r|r|r|c|}
\hline \multirow{2}{*}{} & \multicolumn{3}{|c|}{ Kolmogoror-Smimor } & \multicolumn{3}{c|}{ Shapiro-Wik } \\
\cline { 2 - 8 } & Statistic & \multicolumn{1}{c|}{ df } & \multicolumn{1}{c|}{ Sig. } & Statistic & \multicolumn{1}{c|}{ df } & \multicolumn{1}{c|}{ Sig. } \\
\hline Unstandardized Residual & .096 & 30 & $.200^{*}$ & .982 & 30 & .871 \\
\hline
\end{tabular}

* This is a lower bound of the true significance.

a. Lilliefors Significance Correction

Tabel 6

Model Summary ${ }^{\text {b }}$

\begin{tabular}{|l|l|r|r|r|}
\hline Model & $\mathrm{R}$ & $\mathrm{R}$ Square & \multicolumn{1}{c|}{$\begin{array}{c}\text { Adjusted } \mathrm{R} \\
\text { Square }\end{array}$} & $\begin{array}{c}\text { Std. Error of } \\
\text { the Estimate }\end{array}$ \\
\hline 1 & $.599^{\mathrm{a}}$ & .359 & .312 & 4.582 \\
\hline
\end{tabular}

a. Predictors: (Constant), $X 2, X 1$

b. Dependent Variable: $Y$

Tabel 7

Coefficients $^{2}$

\begin{tabular}{|c|c|c|c|c|c|c|}
\hline \multirow[b]{2}{*}{ How: } & & \multicolumn{2}{|c|}{ Unstandardced Coeficierts } & \multirow{2}{*}{$\begin{array}{c}\begin{array}{c}\text { Standardaed } \\
\text { Coefficients }\end{array} \\
\text { Beta }\end{array}$} & \multirow[b]{2}{*}{1} & \multirow[b]{2}{*}{$\mathrm{Sg}$} \\
\hline & & B & Sta Error & & & \\
\hline \multirow[t]{3}{*}{1} & (Cunstare) & 5.368 & 10858 & & .494 & .625 \\
\hline & $x 1$ & .509 & 498 & 157 & 1.020 & 317 \\
\hline & $x$ & 647 & 175 & 570 & 3.693 & .001 \\
\hline
\end{tabular}

a. DependentVariakle:Y

Tabel 8

\begin{tabular}{|c|c|c|c|c|c|c|}
\hline \multicolumn{7}{|c|}{ ANONA $^{3}$} \\
\hline \multicolumn{2}{|c|}{ Model } & $\begin{array}{l}\text { Sum of } \\
\text { Squares }\end{array}$ & if & Hean Square & $F$ & Sig. \\
\hline \multirow[t]{3}{*}{1} & Regressizn & 317.923 & 2 & 158.962 & 2.571 & $.002^{b}$ \\
\hline & Residual & 566.877 & 27 & 20.995 & & \\
\hline & Total & 884.800 & 29 & & & \\
\hline
\end{tabular}

a Dependert Variakle:Y

b. Presictors: (Consiant, $\times 2 \times 1$ 